\title{
Expression of the bcl-2 protein in B cell lymphomas arising from mucosa associated lymphoid tissue
}

\author{
E Navratil, P Gaulard, P Kanavaros, J Audouin, J Bougaran, N Martin, J Diebold, \\ D Y Mason
}

Department of Pathology, CHU Henri Mondor, Créteil, France E Navratil

P Gaulard

N Martin

Department of

Pathology, University

Hospital, Heraklion,

Greece

P Kanavaros

Department of

Pathology, Hôtel Dieu

Hospital, Paris,

France

J Audouin

J Diebold

Department of

Pathology, CMC

Porte de Choisy,

Paris, France

J Bougaran

Department of

Pathology, John

Radcliffe Hospital,

Oxford

D Y Mason

Correspondence to:

Dr P Gaulard, Départemen

de Pathologie, CHU Henri

Mondor, 51 Avenue du

Maréchal de Lattre de

Tassigny, 94010 Créteil,

France.

Accepted for publication

10 May 1994

\begin{abstract}
Aim-To determine whether lymphomas arising from mucosa associated lymphoid tissue (MALT) express the bcl-2 protein.
\end{abstract}

Methods-Forty two cases of MALT B cell lymphomas, 20 low grade neoplasms and 22 high grade tumours, were studied. Immunohistological staining was performed on paraffin wax embedded tissue using a monoclonal antibody specific for the bcl-2 protein.

Results-All of the low grade lymphomas gave positive results on staining, with clear cytoplasmic labelling for bcl-2 protein in the small neoplastic cells, some of which formed characteristic lymphoepithelial lesions. A striking feature was that larger bcl-2 negative cells were observed in nine of these tumours. They were either scattered singly among the small neoplastic cells or formed small clusters, suggesting that they could represent early areas of transformation to high grade neoplasia. Germinal centres in the vicinity of the tumours lacked bcl-2 protein and hence contrasted clearly with the neoplastic cells. In some cases this permitted germinal centres, which were not obvious on conventional histological staining, to be recognised. In 20 of the 22 cases of high grade $B$ cell lymphoma the large neoplastic cells were bcl-2 negative; the remaining two cases, however, con-

Table 1 Bcl-2 reactivity of MALT lymphomas: Low grade MALT lymphomas

\begin{tabular}{|c|c|c|c|c|}
\hline \multicolumn{4}{|l|}{ Histology } & \multirow{2}{*}{$\begin{array}{l}\text { Bcl-2 staining } \\
\text { Small } \\
\text { neoplastic cell }\end{array}$} \\
\hline Site & $\begin{array}{l}\text { Small } \\
\text { neoplastic cells }\end{array}$ & $\begin{array}{l}\text { Centroblasts } \\
\text { or immunoblasts }\end{array}$ & $\begin{array}{l}\text { Reactive } \\
\text { follicles }\end{array}$ & \\
\hline $\begin{array}{l}\text { Stomach } \\
\text { Stomach } \\
\text { Stomach } \\
\text { Stomach } \\
\text { Stomach } \\
\text { Stomach } \\
\text { Stomach } \\
\text { Stomach } \\
\text { Stomach } \\
\text { Stomach } \\
\text { Colon } \\
\text { Thyroid } \\
\text { Thyroid } \\
\text { Lung } \\
\text { Lung } \\
\text { Lung } \\
\text { Lung } \\
\text { Lung } \\
\text { Salivary gland } \\
\text { Salivary gland }\end{array}$ & $\begin{array}{l}\text { Centrocyte-like } \\
\text { Centrocyte-like } \\
\text { Centrocyte-like } \\
\text { Centrocyte-like } \\
\text { Centrocyte-like } \\
\text { Centrocyte-like } \\
\text { Lymphoplasmocytoid } \\
\text { Lymphoplasmocytoid } \\
\text { Lymphoplasmocytoid } \\
\text { Lymphoplasmocytoid } \\
\text { Centrocyte-like } \\
\text { Centrocyte-like } \\
\text { Lymphoplasmocytic } \\
\text { Centrocyte-like } \\
\text { Centrocyte-like } \\
\text { Centrocyte-like } \\
\text { Centrocyte-like } \\
\text { Centrocyte-like } \\
\text { Centrocyte-like } \\
\text { Centrocyte-like }\end{array}$ & $\begin{array}{l}\text { Absent } \\
\text { Absent } \\
\text { Clusters } \\
\text { Rare } \\
\text { Clusters } \\
\text { Absent } \\
\text { Rare } \\
\text { Rare } \\
\text { Rare } \\
\text { Rare } \\
\text { Absent } \\
\text { Rare } \\
\text { Absent } \\
\text { Rare } \\
\text { Absent } \\
\text { Absent } \\
\text { Absent } \\
\text { Absent } \\
\text { Absent } \\
\text { Absent }\end{array}$ & $\begin{array}{l}\text { Present } \\
\text { Present } \\
\text { Present } \\
\text { Present } \\
\text { Absent } \\
\text { Present } \\
\text { Present } \\
\text { Present } \\
\text { Present } \\
\text { Present } \\
\text { Present } \\
\text { Absent } \\
\text { Absent } \\
\text { Present } \\
\text { Present } \\
\text { Absent } \\
\text { Present } \\
\text { Absent } \\
\text { Present } \\
\text { Present }\end{array}$ & $\begin{array}{l}+++ \\
+++ \\
++ \\
+++ \\
+++ \\
+++ \\
+++ \\
+++ \\
+++ \\
++ \\
+++ \\
+++ \\
++ \\
++ \\
+++ \\
+++ \\
++ \\
++ \\
+++ \\
+++\end{array}$ \\
\hline
\end{tabular}

Staining intensity for bcl-2 is indicated on a scale from negative $(-)$ to strongly positive $(+++)$.

tained a proportion of large neoplastic bcl-2 positive cells. In four of the 22 cases of high grade tumours a low grade component was found which expressed bcl-2 in all cases.

Conclusion-Bcl-2 protein is expressed in low grade, but not in most high grade, MALT lymphomas. In view of recent data indicating that most high grade nodal lymphomas express bcl-2, these findings suggest that MALT lymphomas may regulate $b c l-2$ gene expression differently to nodal lymphomas.

(F Clin Pathol 1995;48:18-21)

Keywords: Bcl-2 protein expression, MALT lymphoma.

Low grade B cell lymphomas originating in mucosa associated lymphoid tissue (MALT) ${ }^{1-6}$ account for a large proportion of extranodal low grade B cell lymphomas. They arise in the gastrointestinal tract but also in other organs which contain MALT, including the lungs and the thyroid and salivary glands. ${ }^{4}$ These lymphomas often take the form of a diffuse infiltration of neoplastic cells, possessing a centrocyte-like morphology, often associated with prominent reactive germinal centres and lymphoepithelial lesions. Low grade B cell MALT lymphomas are characterised by an indolent clinical course and prolonged localisation of the tumour to the original site without dissemination. ${ }^{4}$

The bcl-2 protein is mainly expressed in the inner mitochondrial membrane and can extend cell survival by blocking programmed cell death ("apoptosis"). ${ }^{7}$ It is absent from reactive germinal centres but is often expressed in neoplastic germinal centres in follicular B cell lymphomas, ${ }^{8}$ usually in association with the $14 ; 18$ chromosomal translocation. The expression of bcl-2 protein has also been reported in many types of nodal nonHodgkin's lymphomas, independently of the presence of the $14 ; 18$ translocation. ${ }^{910}$ However, the absence of bcl-2 expression in most cases of MALT high grade $B$ cell lymphoma has been reported $^{11}$ and this prompted us to compare bcl-2 protein expression in low and high grade MALT lymphomas. As labelling was performed on paraffin wax embedded tissue, we were also able to assess the relation between bcl-2 expression and cell morphology. 
Table 2 Bcl-2 reactivity of $M A L T$ lymphomas: High grade $M A L T$ lymphomas associated with a low grade component

\begin{tabular}{|c|c|c|c|c|c|}
\hline \multicolumn{4}{|l|}{ Histology } & \multicolumn{2}{|l|}{ Bcl-2 staining } \\
\hline Site & $\begin{array}{l}\text { Small } \\
\text { neoplastic cells }\end{array}$ & $\begin{array}{l}\text { Large } \\
\text { neoplastic cells }\end{array}$ & $\begin{array}{l}\text { Reactive } \\
\text { follicles }\end{array}$ & $\begin{array}{l}\text { Small } \\
\text { neoplastic cells }\end{array}$ & $\begin{array}{l}\text { Large } \\
\text { neoplastic cells }\end{array}$ \\
\hline $\begin{array}{l}\text { Stomach } \\
\text { Stomach } \\
\text { Ileum } \\
\text { Thyroid }\end{array}$ & $\begin{array}{l}\text { Centrocyte-like } \\
\text { Lymphoplasmocytoid } \\
\text { Centrocyte-like } \\
\text { Lymphoplasmocytoid }\end{array}$ & $\begin{array}{l}\text { Centroblast-like } \\
\text { Immunoblastic } \\
\text { Centroblast-like } \\
\text { Immunoblastic }\end{array}$ & $\begin{array}{l}\text { Present } \\
\text { Present } \\
\text { Present } \\
\text { Present }\end{array}$ & $\begin{array}{l}++ \\
++ \\
++ \\
-\star\end{array}$ & $\begin{array}{l}- \\
-\star \\
-\star \\
-\end{array}$ \\
\hline
\end{tabular}

$\star$ Rare positive cells.

Staining intensity for bcl-2 is indicated on a scale from negative $(-)$ to strongly positive $(+++)$.

Table 3 Bcl-2 reactivity of $M A L T$ lymphomas: High grade $M A L T$ lymphomas

\begin{tabular}{lllll}
\hline Histology & & & & Bcl-2 staining \\
Site & Small & Large & Reactive & $\begin{array}{l}\text { Large } \\
\text { neoplastic cells }\end{array}$ \\
\hline Stomach & Absent & Centroblast-like & Present & - \\
Stomach & Absent & Centroblast-like & Present & - \\
Stomach & Absent & Centroblast-like & Present & - \\
Stomach & Absent & Centroblast-like & Present & - \\
Stomach & Absent & Centroblast-like & Present & - \\
Stomach & Absent & Centroblast-like & Present & - \\
Stomach & Absent & Centroblast-like & Present & - \\
Stomach & Absent & Centroblast-like & Present & - \\
Stomach & Absent & Centroblast-like & Present & - \\
Stomach & Absent & Centroblast-like & Present & - \\
Stomach & Absent & Centroblast-like & Present & - \\
Colon & Absent & Centroblast-like & Present & - \\
Colon & Absent & Centroblast-like & Present & - \\
Ileum & Absent & Centroblast-like & Present & - \\
Ileum & Absent & Centroblast-like & Present & - \\
Ileum & Absent & Centroblast-like & Present & - \\
Ileum & Absent & Centroblast-like & Present & - \\
Ileum & Absent & Centroblast-like & Present & - \\
\hline
\end{tabular}

Staining intensity for bcl-2 is indicated on a scale from negative $(-)$ to strongly positive $(+++)$.

\section{Methods}

All tissue specimens were obtained following surgical resection. The material consisted of 46 cases of B cell lymphoma of MALT origin, including gastric, colorectal, ileal, pulmonary, salivary gland, and thyroid gland lymphomas (tables 1-3). The B cell origin of these tumours was assessed by their reactivity with the L26 (CD20) monoclonal antibody or their monotypic immunoglobulin expression on frozen sections. All samples had been fixed in Bouin's fixative or formalin and embedded

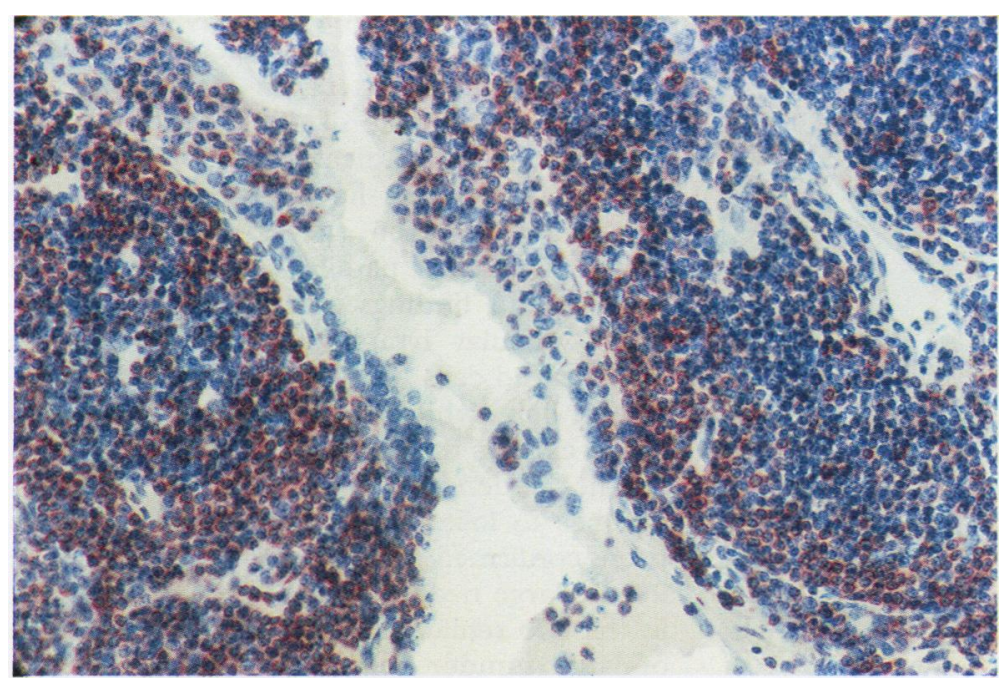

Figure 1 Pulmonary low grade B cell MALT lymphoma. Surface epithelium invaded by centrocyte-like lymphoma cells stained for bcl-2. in paraffin wax. These sections were then cut at $4 \mu \mathrm{m}$ and stained with haematoxylin and eosin and Giemsa stains. Immunostaining was performed on deparaffinised sections by the alkaline phosphatase anti-alkaline phosphatase (APAAP) technique, ${ }^{12}$ using a monoclonal antibody (bcl-2/100) generated against a synthetic peptide. ${ }^{10}$ Of the 46 cases, four were excluded after initial review because of unsatisfactory bcl-2 staining (no staining of any cells, including reactive cells), leaving 42 in which there was clear staining of neoplastic and/or normal cells. Twenty of these cases were classified histologically as low grade and 22 as high grade tumours. In four of the 22 high grade tumours a low grade component was found.

\section{Results}

In all 20 cases (table 1 ) the neoplastic cells were bcl-2 positive (figs 1 and 2). In 15 cases the tumour cells were of centrocyte-like morphology. In four cases most of the tumour cells were of lymphoplasmocytoid morphology and the remaining case was a lymphoplasmocytic tumour. In 14 cases the bcl- 2 positive neoplastic cells were more strongly stained than reactive mantle zone lymphocytes, while in the remaining six cases their labelling was of comparable intensity. Lymphoepithelial lesions were seen in many cases, comprising labelled centrocyte-like cells infiltrating surface epithelium (fig 1). In seven of the 20 cases a small number of large centroblast-like bcl-2 negative neoplastic cells were scattered among the centrocyte-like neoplastic cells, and in two further cases small clusters of such cells could be identified morphologically amongst the smaller neoplastic cells (fig 3 ).

In 15 cases reactive secondary follicles were present in the vicinity of the neoplasm, and in each instance the germinal centre cells were bcl-2 negative (fig 2). In some cases this enabled residual germinal centres to be recognised which were not discernible on conventional histological staining.

The 22 cases in this category were mainly composed of large neoplastic cells resembling centroblasts ( 21 cases) or immunoblasts (one case). In 20 of the 22 cases of high grade B cell lymphomas the large neoplastic cells were bcl-2 negative (fig 4), whereas the remaining two cases contained a few large bcl- 2 positive cells. In four of the 22 cases of high grade tumours a low grade component was found, and three of these expressed the bcl-2 protein (fig 5). In the remaining case most of the neoplastic cells with lymphoplasmocytoid morphology were bcl-2 negative. In each negative case small reactive lymphocytes scattered amongst the neoplastic cells provided an internal positive control (fig 4).

\section{Discussion}

The present study indicates that the bcl-2 protein is expressed by the neoplastic cells in all low grade B cell lymphomas of MALT origin. Although rearrangements of the 


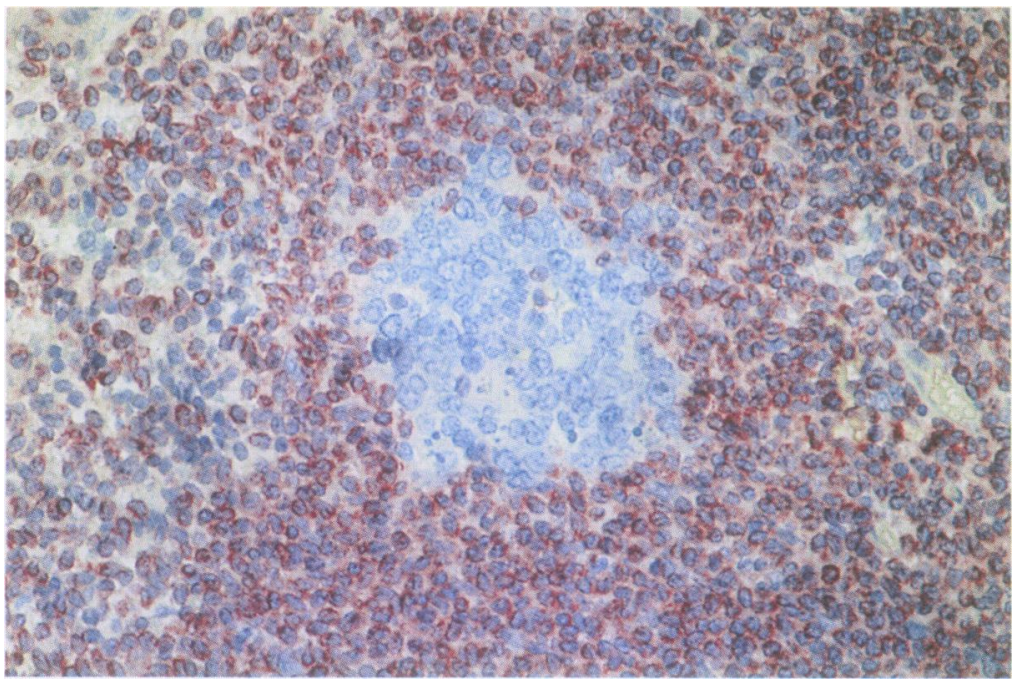

Figure 2 Gastric low grade B cell MALT lymphoma. Centrocyte-like lymphoma cells surrounding a negative reactive follicle.

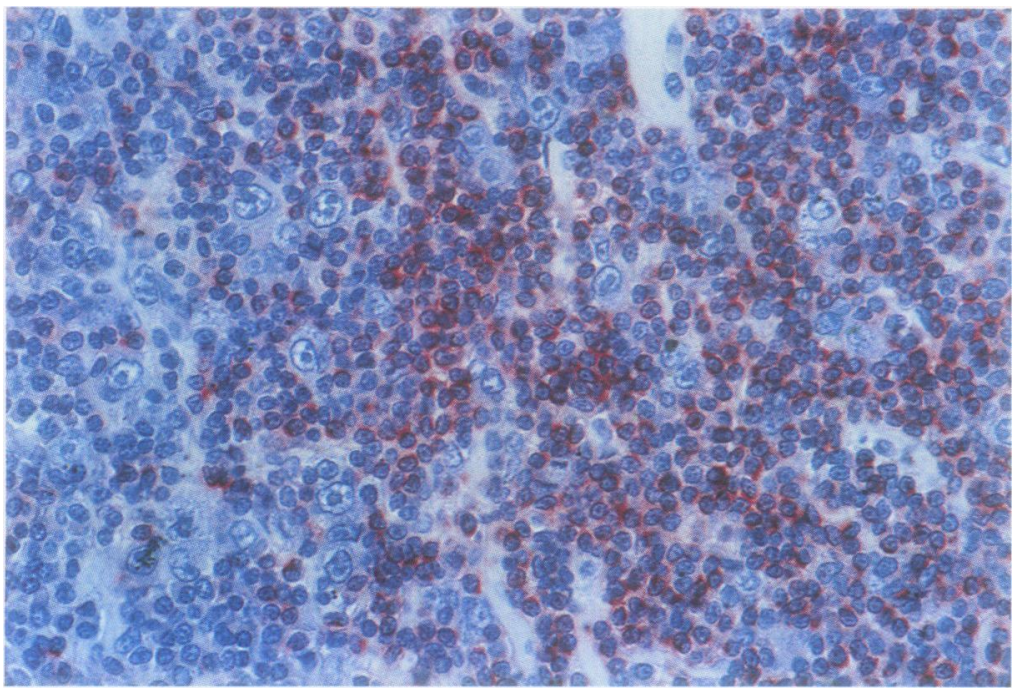

Figure 3 Gastric low grade B cell MALT lymphoma. Centrocyte-like lymphoma cells stained for bcl-2 contrasting with scattered centroblastic and immunoblastic large negative cells.

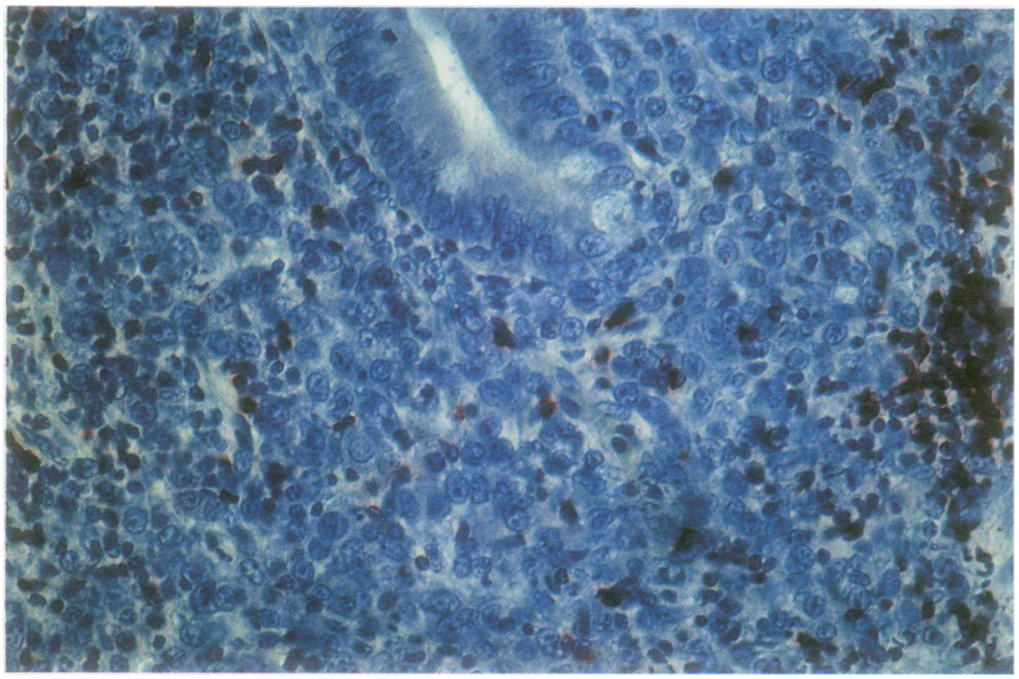

Figure 4 Gastric high grade B cell lymphoma. Neoplastic large cells negative for bcl-2, contrasting with the presence of bcl-2 positive small normal lymphocytes.

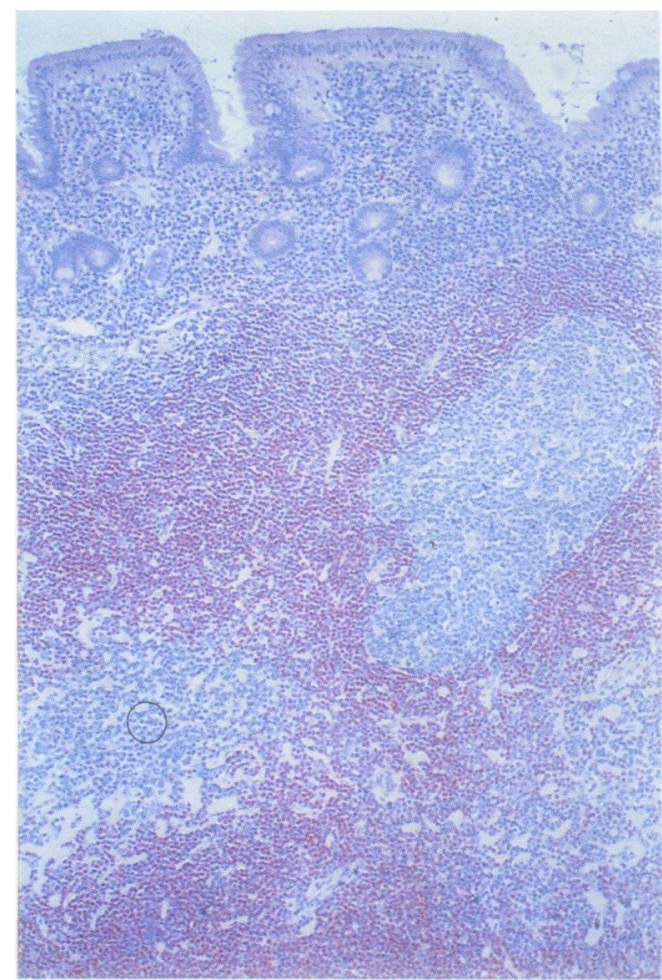

Figure 5 High grade MALT lymphoma associated with low grade B cell MALT lymphoma. Centrocyte-like lymphoma cells stained for bcl-2 surrounding a reactive germinal centre. $O=A$ bcl-2 negative area composed of large "transformed" lymphoid cells.

$b c l-2$ gene have been rarely detected in lymphomas of MALT origin, ${ }^{13-16}$ expression of the bcl-2 protein in MALT lymphomas is not unexpected, as bcl-2 expression has been reported in many node based non-Hodgkin's lymphomas which lack $\mathrm{t}(14 ; 18)$. Bcl-2 protein expression also occurs in Reed-Sternberg cells in some cases of Hodgkin's disease as well as in normal B and T lymphocytes. ${ }^{9} 101718$

Occasionally, the diffuse infiltrate of small centrocyte-like cells, which tends to invade mucosal epithelium to form characteristic lymphoepithelial lesions in low grade B cell MALT lymphomas, may transform into a high grade large cell neoplasm. ${ }^{19}$ It was therefore of interest that large bcl-2 negative cells were seen in the present series, either scattered or in small clusters amongst small bcl-2 positive cells in nine of 20 of the low grade tumours. This indicates that low grade MALT lymphomas have a tendency to lose bcl-2 protein when they progress to high grade tumours. A parallel can be drawn with our previous findings in centroblastic/centrocytic follicular lymphomas, in which large non-cleaved cells (centroblasts) may be negative for bcl-2 while small cleaved cells (centrocytes) express this protein strongly. ${ }^{8}$

The tendency of high grade MALT lymphomas to lose bcl-2 protein expression has been confirmed in the present series as in 20 the large neoplastic cells lacked bcl-2 and in the two remaining cases only a proportion of large tumour cells expressed bcl-2. This contrasts with the bcl-2 positive results reported in most cases of nodal large $B$ cell 
lymphoma ${ }^{11}{ }^{18}$ but is in keeping with the previous observation that most large cell MALT lymphomas are bcl-2 negative. ${ }^{1120}$ This suggests that MALT lymphomas differ from nodal lymphomas in the regulation of $b c l-2$ gene expression. ${ }^{14}$ The absence of detectable bcl-2 protein in most high grade MALT lymphomas could reflect a breakdown in bcl-2 gene expression at the transcriptional or the post-transcriptional level. The possibility of post-transcriptional breakdown in $b c l-2$ gene expression has been considered based on discordant bcl-2 messenger RNA (mRNA) and bcl-2 protein expression in reactive lymph nodes. ${ }^{2021}$ In addition, stimulatory and inhibitory mechanisms of $b c l-2$ gene expression at the transcriptional and posttranscriptional level have been described in human proliferating lymphocytes and lymphonodal lymphomas. ${ }^{22}$ Further studies showed that proliferating normal lymphoid cells fail to express the bcl-2 protein. $^{10}$ Therefore, the absence of bcl-2 protein expression in most high grade MALT lymphomas may be related to their high rate of proliferation. In this respect Isaacson et al ${ }^{24}$ have shown that colonised follicles in MALT lymphomas are bcl-2 negative. This finding may be related to the high proliferation rate in colonised follicles, or to physiological downregulation of bcl-2 in the follicular environment. ${ }^{24}$

The clinical and prognostic importance of the absence of bcl-2 protein expression in high grade MALT lymphomas when compared with high grade lymphonodal lymphomas has not been established. However, high grade MALT lymphomas exhibit a better prognosis than high grade lymphonodal lymphomas. ${ }^{25}$ This might be related to findings that bcl-2 positive high grade lymphomas have a shorter disease free survival than bcl-2 negative ones ${ }^{18}$ and that a $\mathrm{B}$ leukaemic cell line with elevated bcl-2 protein levels exhibits a strikingly long survival when cultured in the presence of antineoplastic drugs. ${ }^{26}$

1 Isaacson PG, Wright DH. Malignant lymphoma of mucosa-associated lymphoid tissue. Cancer 1983;52: 1410-16.

2 Isaacson PG, Wright DH. Extranodal malignant lymphoma arising from mucosa-associated lymphoid tissue. Cancer 1984;53:2515-24.

3 Isaacson PG, Spencer J, Finn T. Primary B cell gastric lymphoma. Hum Pathol 1986;17:72-82.

4 Isaacson PG, Spencer J. Malignant lymphoma of mucosaassociated lymphoid tissue. Histopathology 1987;11:445-62.
5 Moore I, Wright DH. Primary gastric lymphoma. A tumour of mucosa-associated lymphoid tissue. A histological and immunohistological study of 36 cases. Histopathology 1984;8:1025-39.

6 Myhre MJ, Isaacson PG. Primary B cell gastric lymphoma. A reassessment of its histogenesis. $\mathcal{F}$ Pathol 1987;152: $1-11$.

7 Hockenbery D, Nunez G, Milliman C, Schreiber RD, Korsmeyer SJ. Bcl-2 is an inner mitochondrial membrane protein that blocks programmed cell death. Nature 1990;348:334-6.

8 Gaulard P, d'Agay MF, Peuchmaur M, Brousse N, Gisselbrecht C, Solal-Celigny P, et al. Expression of the bcl-2 gene product in follicular lymphoma. Am f Pathol 1992;140:1089-95.

9 Zutter M, Hockenbery D, Silverman GA, Korsmeyer SJ. Immunolocalization of the bcl-2 protein within hematopoietic neoplasms. Blood 1991;78:1062-68.

10 Pezzella F, Tse AGD Cordell JL Pulford KAF, Gatter KC, Mason DY. Expression of the bcl-2 oncogene protein is not specific for the $14 ; 18$ chromosomal translocation. Am F Pathol 1990;137:225-32

11 Villuendas R, Piris MA, Orradre JL, Mollejo M, Rodriguez $R$, Morente $M$. Different bcl-2 protein expression in high-grade B-cell lymphomas derived from lymph node or mucosa-associated lymphoid tissue. Am $\mathcal{F}$ Pathol 1991;139:989-93.

12 Cordell JL, Falini B, Erber WN, Ghosh AK, Abdullaziz Z, MacDonald $S$, et al. Immunoenzymatic labelling of monoclonal antibodies using immune complexes of alkamonoclonal antibodies using immune complexes of alkaline phosphatase and monoclonal antialkaline phosphatase (APAAP)

13 Raghoebier S, Kramer MHH, van Krieken JHJM, de Jong D, Limpens J, Kluin-Nelemans JC, et al. Essential differences in oncogene involvement between primary nodal and extranodal large cell lymphoma. Blood 1991;78: 2680-5.

14 Pan L, Diss TC, Cunningham D, Isaacson PG. The bcl-2 gene in primary B cell lymphomas of mucosa-associated lymphoid tissue (MALT). Am $\mathcal{F}$ Pathol 1989;135:7-11.

15 Straka C, Mielke B, Eichelman, Trede I, Ho AD, Möller P. Bcl-2 gene rearrangements in primary B-cell lympol of the phomas of the gastrointestinal tract reveal follicu
lymphoma as a subtype. Leukemia 1993;7:268-73.

16 Kerrigan DP, Irons J, Chen I-M. Bcl-2 gene rearrangement in salivary gland lymphoma. Am $\mathcal{F}$ Pathol 1990; ment in saliva

17 Jiwa NM, Kanavaros P, van der Valk P, Walboomers JMM, Horstmann A, Vos W, et al. Expression of c-myc and bcl-2 oncogenes products in Reed-Sternberg cells independent of presence of Epstein-Barr virus. $\mathcal{f}$ Clin Pathol 1993;46:211-17.

18 Hermine $\mathrm{O}$, Haioun $\mathrm{C}$, Lepage $\mathrm{E}$, d'Agay MF, Brière J, Tilly $\mathrm{H}$, et al. Bcl-2 protein expression in aggressive nonHodgkin's lymphomas (NHL). A new adverse prognostic factor [abstract]. Br 7 Haematol 1994;87(Suppl 1):220.

19 Chan JKC, Ng CS, Isaacson PG. Relationship between high grade lymphoma and low grade B-cell mucosahigh grade lymphoma and low grade B-cell mucosaassociated lymphoid tissue lymphoma (MAL

20 Kondo E, Nakamura S, Onone H, Matsuo Y, Yoshino T, Aoki $\mathrm{H}$, et al. Detection of bcl-2 protein and bcl-2 mRNA in normal and neoplastic lymphoid tissues by immunohistochemistry and in situ hybridization. Blood 1992;80:2044-51

21 Chleq-Descamps C, Le Brun D, Huie P, Besnier DP, Warnke RA, Sibley RK, et al. Topographical dissociation of bcl-2 mRNA and bcl-2 protein expression in human lymphoid tissues. Blood 1993;81:293-8.

22 Reed JC, Tsujimoto Y, Alpers JD, Croce CM, Nowel PC. Regulation of bcl-2 protooncogene expression during normal human lymphocytic proliferation. Science normal human 98 .

23 Tsujimoto Y, Croce CM. Analysis of the structure, transcripts and protein products of the bcl-2, the gene involved in human follicular lymphoma. Proc Natl Acad Sci USA 1986;83:5214-18.

24 Isaacson PG, Wotherspoon AC, Diss TC, Pan LX. Bcl-2 expression in lymphomas. Lancet 1991;337:175-6.

25 Cogliatti SB, Schmid U, Schumacher U, Eckert F Hansmann ML, Hedderich J, et al. Primary B-cell gastric lymphoma: a clinicopathological study of 145 patients. Gastroenterology 1991;101:1159-70.

26 Miyashita T, Reed JC. Bcl-2 oncoprotein blocks chemotherapy-induced apoptosis in a human leukemia cell line. Blood 1993;81:151-7. 